\title{
Brazilian Science and Research Integrity: Where are We? What Next?
}

\author{
SONIA M.R. VASCONCELOS ${ }^{1}$, MARTHA M. SORENSON $^{1}$, EDSON H. WATANABE $^{2}$, \\ DEBORA FOGUEL ${ }^{1}$ and MARISA PALÁCIOS ${ }^{3}$ \\ ${ }^{1}$ Programa de Educação, Gestão e Difusão em Biociências (PEGeD), Instituto de \\ Bioquímica Médica Leopoldo de Meis (IBqM), Universidade Federal do Rio de \\ Janeiro (UFRJ), Av. Carlos Chagas Filho, 373, 21941-902 Rio de Janeiro, RJ, Brasil \\ ${ }^{2}$ Programa de Engenharia Elétrica (PEE), Instituto Alberto Luiz Coimbra de \\ Pós-Graduação e Pesquisa de Engenharia (COPPE), Centro de Tecnologia, \\ Av. Horácio Macedo, 2030, UFRJ, 21941-972 Rio de Janeiro, RJ, Brasil \\ ${ }^{3}$ Programa de Pós-Graduação em Bioética, Ética Aplicada e Saúde Coletiva, \\ UFRJ, UFF, UERJ e FIOCRUZ, Departamento de Bioética/IESC/UFRJ, \\ Praça Jorge Machado Moreira, 100, 21944-970 Rio de Janeiro, RJ, Brasil
}

Manuscript received on March 2, 2015; accepted for publication on March 25, 2015

\begin{abstract}
Building a world-class scientific community requires first-class ingredients at many different levels: funding, training, management, international collaborations, creativity, ethics, and an understanding of research integrity practices. All over the world, addressing these practices has been high on the science policy agenda of major research systems. Universities have a central role in fostering a culture of research integrity, which has posed additional challenges for faculty, students and administrators - but also opportunities. In Brazil, the leading universities and governmental funding agencies are collaborating on this project, but much remains to be done.
\end{abstract}

Key words: Responsible conduct of research, academic integrity, science policy, research ethics education, international collaborations, 4th World Conference on Research Integrity.

\section{INTRODUCTION}

In its 2011 report "Knowledge, Networks and Nations", The Royal Society (2011) provided an overview of the scientific landscape for the $21^{\text {st }}$ century, particularly for global scientific collaborations. This report describes growing participation of emerging scientific powers such as Brazil in international research networks,

Correspondence to: Sonia Vasconcelos

E-mail: svasconcelos@bioqmed.ufrj.br and attributes this growth in part to increasing expenditures in Research and Development (R\&D). The report shows Brazil's ambitious goal of spending 2.5\% of GDP (Gross Domestic Product) on R\&D by 2022, up from less than $1.5 \%$ in 2007. This goal for investment in R\&D is similar to that of rising powers, such as China, for 2020. As stated in a recent economic survey by the Organization for Economic Cooperation and Development (OECD 2013), "Brazil has moved up the ranks 
of the world's largest economies while achieving much more inclusive growth than in the past."

In terms of research productivity measured by scientific articles published annually, Brazil ranks $15^{\text {th }}$ (SJR 1996-2013), according to the indicators compiled by SCImago Journal \& Country Rank from the Scopus ${ }^{\circledR}$ database. Brazil accounts for almost $3 \%$ of global scientific output, which represents more than $60 \%$ of the science produced in Latin America (Van Noorden 2014a). This figure is particularly relevant for the visibility of Brazilian science and is partially explained by GDP investments in R\&D. However, compared to the OECD countries, for example, research outputs for Brazil (including articles published in top-tier scientific journals as well as patents/ trademarks) are still low (OECD 2012).

In fact, while the country has made considerable progress in contributing to world science in the last decades, it still faces important challenges. Among these are increasing the number of researchers in scientific and technological fields, reducing bureaucracy for purchasing equipment and reagents, making adjustments to regulatory law, and strengthening the internationalization of its national research system (Krieger 2014). Concerning the latter, Brazil has much room to improve. As Adams (2012) has recently shown, for China, India, South Korea and Brazil, $75 \%$ of the research output arises from domestic collaborations. Compared to Argentina, for example, Brazil has established fewer international partnerships, as can be noted for publications in the 1996-2013 period (SJR 1996-2013).

Today, the internationalization of science is highly desirable, and it is expected that the growing gap between solely national versus international collaborative research "will influence each nation's ability to draw on the global knowledge base" (Adams 2012, 2013). However, tough challenges arise when collaborations involve countries with different research cultures and systems. Ethical challenges in building international research networks have recently drawn particular attention from researchers, educators and policymakers. At the policy level, for instance, ethical concerns have been high on the agenda of the OECD countries over the last couple of years. The OECD already expressed these concerns in conversations during the OECD Global Science Forum in 2007 (OECD 2007). In the same year, the European Science Foundation (ESF 2007) raised similar issues in its Policy Briefing "Research Integrity: Global Responsibility to Foster Common Standards". In 2011, the American Association for the Advancement of Science (AAAS) discussed emerging ethical questions in collaborative research networks, at its "Science without Borders" meeting (AAAS 2011).

From a global perspective, The Montreal Statement on Research Integrity (2013) expresses the view that incentives to international collaborations in research should be accompanied by the development of initiatives to identify barriers that may compromise the quality of collaborative endeavors. According to Subra Suresh, former president of the National Science Foundation (NSF), "the most fundamental barriers to bilateral and multilateral international collaborations are disparate standards for scientific merit review and differences in the infrastructures that ensure professional ethics and scientific integrity." (Suresh 2011). Notions of integrity in research seem to have a particular impact on collaborations between emerging and established scientific powers (NAS 2010). In an increasingly diverse, collaborative research network, different ethical criteria for conducting research projects on humans and animals, for sharing authorship in scientific papers and for handling allegations of research misconduct, for example, may be sources of conflict (Anderson and Steneck 2010, NAS 2010, The Montreal Statement 2013). As already pointed out elsewhere, ensuring harmonious interactions among scientists from different research systems does not seem to be a trivial task when it comes to issues in research ethics and integrity (Anderson and Steneck 2010, Vasconcelos et al. 2012). 
In this context, Brazil has demonstrated growing awareness of research integrity and its implications for international collaborations. Although its universities are still young and the internationalization of its research needs to be reinforced, the country has taken an emerging role in international initiatives toward the topic. Brazil, for example, has a seat on the Governing Board of the Global Research Council (GRC), established in 2012. Conversations at the GRC were driven in part byneed for harmonization of policies on merit review and research integrity for projects among global research funders and other scientific organizations supporting research. With a steady contribution to the GRC, the Brazilian National Council for Scientific and Technological Development (CNPq) has staked out a role for Brazil as a player in global discussions on research integrity and funding. In 2013, the country was selected to host the next World Conference on Research Integrity $\left(4^{\text {th }}\right.$ WCRI 2015), the major international forum addressing the topic, traditionally encompassing contributions from more than 50 countries. But these are only part of the country's engagement in conversations about research integrity.

In this report, we thus provide an overview of whereBrazil fits into these international conversations and where it stands in terms of local efforts to foster a culture of RI/RCR. We also look at some of the challenges facing developing institutional initiatives in the country. Overall, we offer a panorama of Brazil's contribution to research integrity policies on the local and international scenes.

\section{BRAZILIAN INITIATIVES TO ADDRESS RESEARCH INTEGRITY - COMBINED EFFORTS}

Historically, initiatives to address research integrity have been driven by a number of factors, which include gradual changes in the dynamics of doing, publishing, and funding research, in the public perception of science, and in science policy (Jaroff 1991). Particularly in the last two decades, the research landscape in terms of funding, accountability for research results and their social impact has reflected growing interactions between science and society (Kreutzberg 2004, Velho 2011, Schacht 2012). In this context, research misconduct has attracted attention not only from the scientific community but from policymakers and from the public itself (Jaroff 1991, Dingell 1993, Kreutzberg 2004).

Currently, it is not clear whether the growing number of research misconduct cases in the last decades is the result of an increase in this practice or of better detection systems (Fang et al. 2012), but attention to this ethical problem is going global. Today, institutional mechanisms to handle research misconduct allegations are expected to be part of the approach to research integrity for all research systems (The Singapore Statement on Research Integrity 2010, The Montreal Statement 2013). A quick survey of global responses to what appears to be an upsurge in research misconduct of various kinds reveals a broad range of misadventures: ministers falling in Europe (Editorial 2012, Kupferschmidt 2013), researchers censured in Japan (Normile 2014a, b), top governmental science advisors embarrassed in India (Jayaraman 2012), a professor at Harvard forced to resign (Carpenter 2012), hundreds of plagiarized papers in China (Zhang 2010), authors and editors from different countries embroiled in peer-review scams and citation stacking. Brazil is not immune (Van Noorden 2014b, Ferguson et al. 2014). As recently pointed out by Nicholas Steneck, Brazil has "joined the club" (Alisson 2014) when it comes to problems of research misconduct.

Curiously, awareness of RI/RCR appears to be taken for granted by most scientists, irrespective of nationality. This idea is aligned with Kreutzberg's (2004) observation that "science and scientists have been entrusted to set up their own rules, based on trust, respect and the welfare of society" and that "when scientists hear about scientific fraud, they quickly denounce the culprits as not 
being 'true' scientists. The true scientist, they argue, is only interested in unveiling step by step the countless enigmas of nature". This feeling may partially explain the slow pace of research integrity educational policies for different systems and cultures, including Brazil. We suspect that, for Brazil, this educational lag time means that RI/ RCR discussions will take some time to evolve into widespread educational policies at the country's universities. On the other hand, we should consider that the challenge associated with building a culture of research integrity for any country may be tougher than we expect. Senior and early-career researchers alike are expected to engage in RI/ RCR training initiatives, but generally speaking, researchers do not feel naturally prepared to teach research integrity systematically to their students. As a matter of fact, senior and junior researchers alike need to become more familiar with emerging ethical issues that may affect the way both groups propose, conduct, communicate and review science.

In Brazil, only a few initiatives devoted to RI/RCR education have been developed at the graduate level. One of these was the credit course focusing on RCR implemented in 2007 at the Military Institute for Engineering (IME) in Rio de Janeiro (IME, Ética na Pesquisa Cientifica e Tecnológica 2012). To our knowledge, this was the first RCR course in Brazil to address specific issues on research integrity and specifically designed for science and technology graduate students. In 2011, a course devoted to RCR was implemented at the Institute of Biophysics Carlos Chagas Filho at the Federal University of Rio de Janeiro (IBCCF/ UFRJ), entitled "Ethics and Integrity in Scientific and Technological Research" (Ética e Integridade na Pesquisa Científica e Tecnológica). In 2015, the Institute of Medical Biochemistry Leopoldo de Meis (IBqM 2015) will start to offer "Responsible Conduct of Research" (Conduta Responsável em Pesquisa) for graduate students.
A few Brazilian universities have combined courses on the scientific method with topics on RI/ $\mathrm{RCR}$, which may turn out to be a useful strategy. One of the more recent initiatives of this type is found at the Alberto Luiz Coimbra Institute for Graduate Studies and Research in Engineering (COPPE/ UFRJ). With an 8-hour course entitled "Scientific Methodology and Research Ethics" (Planeta Coppe 2012), COPPE launched an extramural initiative to discuss the relationship between these two topics and their importance in research developed at the university. Now in its fourth edition, this course has reached an audience of about 150 participants per year, which includes undergraduate and graduate students, besides professors and others interested in the topic, from any institution or background. This initiative has brought up issues concerning the communication of science and publication ethics for an audience that extends well beyond novice and experienced academics. Since 2013, all classes have been freely available through TV COPPE.

In 2014, the Faculty of Medicine of Ribeirão Preto of the University of São Paulo (USP) (FMRPUSP 2014), initiated a course for undergraduate students in Biomedical Sciences to discuss emerging issues in research ethics and integrity. Recently, we have learned that a novel approach to RI/RCR has been launched by the Pontifical Catholic University of Rio Grande do Sul (PUCRS 2014) in the form of a training program aimed at undergraduate students doing "scientific initiation" research projects. The program includes an e-book on research ethics and integrity written by professors from different fields and is mainly designed for undergraduates. Seminars and other activities on RI/RCR are now held regularly at PUCRS.

In Brazil, these efforts are aligned with the creation of the Brazilian Meeting on Research Integrity and Publication Ethics (BRISPE), in 2010. The I BRISPE (2010) was the result of a postdoctoral research project on RI/RCR at UFRJ developed by one of the authors (SMRV), which was supported 
by the Carlos Chagas Filho Foundation for Research Support in Rio de Janeiro (FAPERJ). The I BRISPE was an initial attempt to draw national attention to RCR. Late in 2010, an itinerant five-day forum organized by COPPE/UFRJ and IBqM/UFRJ began in Rio de Janeiro at COPPE, with a small group of international speakers and one or two Brazilians to discuss quantitative and qualitative aspects of RCR. After a day at the Brazilian Center for Physics Research (CBPF) and another at USP, the forum came to a close at the joint facilities of the National Institute for Space Research (INPE) and The InterAmerican Institute for Global Change Research - (IAI), in São José dos Campos, in São Paulo. Funding was modest and audiences were small, but most listeners heard for the first time an international perspective on the history of RCR, on the work done by an international association of journal editors (Committee on Publication Ethics, COPE) and on academic plagiarism, including software tools for detecting copy-paste. A fledgling network began to form, focused on RI/RCR.

The II BRISPE (2012) was a more ambitious event, with 14 international contributors out of a total of 30. Speakers from abroad travelled from UFRJ and the Oswaldo Cruz Foundation (FIOCRUZ) in Rio de Janeiro to USP in São Paulo, and finally, on day 4, to PUCRS, in Porto Alegre. New topics on the agenda included conflicts of interest, copyrights and patents, biodiversity and biopiracy, and strategies for maintaining successful collaborations across national borders. The question of training programs at universities and research institutes was the subject of one session. An important contribution on plagiarism in high schools underlined the difficulty in obtaining quantitative data on this topic, and at COPPE, a two-day course on scientific writing and publication ethics attracted young professors as well as graduate students. With an audience of approximately 550 overall, it was evident that there was real progress toward the goal of raising awareness of research integrity in Brazil.
The international speakers were recruited by the BRISPE organizers to discuss the possibility of Brazil hosting the $4^{\text {th }}$ World Conference on Research Integrity ( $4^{\text {th }}$ WCRI 2015), and an extended session on the links between research integrity, quality and accountability led to the Joint Statement on Research Integrity in English, Portuguese and Spanish (http://www.iibrispe.coppe.ufrj.br/index. php/jointstatement). Lingering memories of a 35year dictatorship and remnants of authoritarian practices that persist in Latin America make this Statement a distinctly Brazilian document about RI/ $\mathrm{RCR}$ - one that emphasizes preventing misconduct by educating and training young scientists and improving scientific outcomes rather than catching and punishing miscreants.

Looking at research integrity even more broadly, in 2011, Brazil's two largest research agencies, FAPESP (The State of São Paulo Research Foundation) and CNPq, both published RI/RCR guidelines (FAPESP 2014a, CNPq 2014) in a clear and public signal of concern. Aligned with these efforts, the Brazilian Academy of Sciences (ABC 2013) presented their version in 2013. The guidelines of CNPq are focused on authorship, plagiarism, and publication ethics. Penalties are not mentioned, and cases are not made public. FAPESP, whose budget for funding research in the state of São Paulo is nearly as large as that of $\mathrm{CNPq}$, has embarked on a campaign to stimulate awareness of research integrity issues and compliance with good research practices among its grantees, who account for more than half of the Brazilian research output. In October 2014, the FAPESP website (FAPESP 2014b) began to provide online summaries of proven misconduct cases involving grantees. FAPESP's campaign includes a regular section, "Ética", in Revista Pesquisa FAPESP, with comments on RCR items from the national and international press.

In August of 2014, FAPESP sponsored the third national meeting (III BRISPE 2014a), focusing on institutional policies to foster RCR in 
Brazilian institutions. For this meeting, speakers from Europe, the US and Brazil presented different perspectives on RCR education (Agência FAPESP 2014). Invitations were sent to funding agencies, policymakers and deans responsible for graduate programs and research at all of Brazil's federal, state and some private universities. The III BRISPE included a strategy meeting for stimulating interest in Brazil's role as host of the $4^{\text {th }}$ WCRI and maximizing participation of Brazilian delegates (III BRISPE 2014b).

\section{RESEARCH INTEGRITY AT BRAZILIAN} UNIVERSITIES: SEEKING AN EFFECTIVE APPROACH

As we have shown, although RI/RCR educational actions may take time to evolve, there is growing awareness of research integrity issues among faculty, students, policymakers and administrators in Brazil. At Brazilian universities, faculty and research administrators have an enormous challenge to embrace, as fostering a culture of research integrity includes finding effective mechanisms to handle research misconduct and questionable research practices. In the last few years, the role of universities in promoting and sustaining research environments that encourage $\mathrm{RI} / \mathrm{RCR}$ has been central. This central role has been pinpointed in recently launched documents such as The Singapore Statement on Research Integrity (2010) and others (Wager and Kleinert 2012, Macquarie University 2014). In Brazil, RI/RCR actions in some universities have been partially triggered by research misconduct allegations (Esteves 2011, 2012, 2014). The responses to these allegations have, in some instances, been energetic, as described in this article on a case at the University of São Paulo (Takahashi 2011):"“The President's office has determined the dismissal of a full-time faculty member with more than 15 years at USP, on reaching the conclusion that he was responsible for a publication that plagiarized publications of other investigators."
In a news item published in Gazeta do Povo of Londrina (PR) in 2012 (Czelusniak 2012), one reads “Universities Take Up Arms Against Plagiarism":

"Universities are redoubling their efforts to inhibit the practice of plagiarism in monographs, dissertations and theses - a practice that sullies the image of both the investigator and the institution for accepting work that is not original. Among the sanctions that may be applied when copying is proven are retraction of the work and suspension or expulsion of the student. In addition, the student may be hauled into court for violating copyright laws."

The article goes on to describe an "anti-plagiarism squad" in one university where a group applies various tools to identify plagiarism in monographs, theses and dissertations at that institution. Increasingly, in an attempt to tackle plagiarism, one of the most sensitive issues in RI/RCR, universities have used plagiarism detection software, and this is especially true for institutions in established scientific powers $\left(6^{\text {th }}\right.$ International Integrity \& Plagiarism Conference 2014). The motivations include the prevalence of the problem at different universities and levels (Park 2003, McCabe 2005, Comas-Forgas et al. 2010, Heitman and Litewka 2011). While these initiatives demonstrate institutional concern over the impact of plagiarism on the intellectual production of universities, their credibility as centers of excellence producing quality knowledge and human resources is also at stake. Yet, dealing with problems of academic integrity at the university has called for broad approaches to education and pedagogy (Howard 2007, Power 2009, Bretag 2013). One of the issues on plagiarism among students, for example, is that while detection software may reduce this practice (Davis and Carroll 2009), the use of this tool alone is not sufficient to eliminate the practice at universities. It has been demonstrated that adopting educational and preventive measures rather than using deterrents and penalties may be more effective to tackle the problem (Dee and Jacob 2010). 
All over the world, many universities have taken this educational challenge seriously. In the US, for example, which has an established tradition of integrity policies at the university level, the Council of Graduate Schools (CGS) plays an important role in stimulating best practices among American universities and colleges. The CGS "is committed to advancing the scope and quality of graduate education in the ethical and responsible conduct of research. Since 2003, CGS has worked with members to develop promising practices in RCR and research ethics education for graduate students" (CGSa - Best Practices). The Council has made important contributions to advancing approaches to integrity in academic research in science and engineering, for example, through partnerships with the US Office of Research Integrity (CGSb - The Project for Scholarly Integrity).

In Europe, there is quite a diverse scene when it comes to research integrity policies at institutions. The League of European Research Universities (LERU) has attempted to catalyze efforts directed toward research integrity in a number of universities (Löfström 2014, Clavey 2014). The UK has advanced at a steady pace towards the implementation of research integrity policies in its research systems, and UK universities have been encouraged to be pro-active in educational actions. The Universities UK-Concordat to Support Research Integrity (The Concordat to Support Research Integrity 2012) seems to reflect, in part, these actions. The Concordat places the university within a complex (and real) research environment with different stakeholders that are equally responsible for sustaining integrity in all research endeavors.

In Brazil, we have a long road ahead of us in this area, and Brazilian universities will need to experiment with different approaches to RI/ RCR among faculty, staff and students. At present, although $\mathrm{CNPq}$ and especially FAPESP have made efforts to draw Brazil's research community into the circle, very few universities have taken up the challenge to act (Marques 2014). We need to accelerate this process, as it is mostly at the university where authors and investigators are trained, and it is mostly at the university where they carry out the research that will be presented to peers and, eventually, to the public. These institutions are responsible not only for parceling out the workspace, but also for setting up the rules of the game, investing in academic inquiry into ethical conduct and learning to manage factors that prevent or promote responsible conduct in research. The university is expected to implement concrete policies for good practices that can be revisited from time to time, as new knowledge and new questions in research are posed to the university community and to society.

At the beginning of this report, we cited Kreutzberg's view (2004) of scientists' idea of honesty. Aligned with this idea, one of the difficulties that an institution must face is that a substantial number of its members equate integrity in research with honesty. On this assumption, being honest would ensure that a person behaves with integrity. In principle, we should be able to count on this virtue in academia, but research institutions cannot rely solely on virtues, as they may be challenged by different kinds of incentives in the current research environment. Therefore, elaborating, implementing, and evaluating the effectiveness of appropriate policies to address the responsible conduct of research activities are expected to be part of the agenda of the university. The problem of academic dishonesty also requires much closer attention than it currently receives in most university settings.

This was the spirit that motivated the creation of the Advisory Council for Research Ethics (CTEP; http://www.ctep.ufrj.br/) at UFRJ. With the encouragement of the Provost for Graduate Studies and Research, this group arose from a small nucleus of faculty and administrators associated with graduate programs, mostly in the health sciences, 
but from other areas as well, such as engineering and the humanities. Between August 2012 and July 2013, when the Council formally started its activities, it elected to embrace 6 topics in research ethics and integrity: research on human subjects, research on animals, research using biodiversity and traditional knowledge associated with genetic resources, biosafety and biosecurity, and RI/ RCR. This led to the creation of 6 subcommittees, with around 30 people committed to working on educational measures to address the 6 topics.

The idea behind CTEP was to create a unit combining the expertise of UFRJ in several research areas so that its different subcommittees could provide advice for the UFRJ community concerning ethical issues arising in planning, funding and conducting research, collaborating with peers, caring for the environment, recording and communicating results and evaluating project proposals. This Advisory Council, in the university hierarchy, is constituted as a collegiate body with the mission to provide consultation, information, education and proposals for action or policies related to the 6 topics (Foguel 2014). The Council is directly subordinate to the office of the Provost for Graduate Studies and Research, and responds to the Provost, who presides over it. In addition to specialists in each area, CTEP includes representatives of pre-existing regulatory bodies, which are distributed throughout different university research centers and are responsible for assessing research proposals, mostly for ethics and compliance with federal regulations: Research Ethics Committee (CEP), Animal Ethics Committee (CEUA), Biosafety Commission and the Innovation Agency.

CTEP also interacts with graduate programs in an effort to stimulate a critical stance at all levels of the research endeavor and ethical considerations related to knowledge generated by such endeavor. When it comes to RI/RCR, the Advisory Council expects to foster a research climate in which research ethics and integrity have a real place in decisions on many aspects of the research activities conducted at the university. This expectation has recently been expressed in the Guidelines for Academic Integrity (http://cpro16197. publiccloud.com.br/ ctep/diretrizes/Diretrizes $\% 20$ Integridade $\% 20$ Academica_versao $\% 2026 \% 2009$. pdf). These guidelines were available online for 6 weeks for members of the UFRJ community to have their say on the document before making it official. One of the goals of this phase was to trigger discussions, for example, on authorship issues and conflict of interests in different kinds of collaborative endeavors in the UFRJ academic community, irrespective of field.

\section{CONCLUSIONS}

As we have shown, Brazil is beginning to recognize that research integrity and related concerns have an important role to play in the country's panorama of research, science education, funding, and policy. Evidence that the Brazilian research system has made research integrity issues an important asset for its development and quality can be found in the level of involvement among Brazilian funding agencies and many scientific organizations in the proposal for Brazil to host the $4^{\text {th }}$ WCRI. This proposal was supported by CNPq, FAPESP, FAPERJ and the Coordination for the Advancement of Higher Education Personnel (CAPES), the Brazilian Society for the Advancement of Science (SBPC) and the Brazilian Academy of Sciences $(\mathrm{ABC})$, among many others.

What we expect to see now is marked participation of universities and many other research institutions, organizations and groups represented at this world event in Rio, in 2015. The outcome of this world conference for Brazil is expected to be broader recognition in the country that research governance and integrity are closely related, and therefore, identifying ways to strengthen this relationship should be among the priorities of the agenda of the Brazilian research 
system. As we have argued, research integrity has shaped institutional policies for major research systems all over the world and has had a strategic role in fostering accountability and public trust in the science produced by these systems. Universities are at the core of these policies, particularly in developed countries that collaborate with Brazil. This current landscape has shown gradual changes in perceptions of the responsible conduct of research among research institutions, authors and funders. Although established scientific powers have taken the lead in objective actions to deal with these changes, emerging countries such as Brazil have played an increasing role in research integrity conversations. But this engagement should be a non-stop process, as the long-term success of initiatives that have been taken in Brazil will depend on all of those participating in the country's research chain. This is a challenge that all Brazilian faculty and thesis advisors should embrace.

Perhaps CNPq and CAPES could call for all grantees and graduate programs to design and implement new tools for promoting education in the responsible conduct of research among junior researchers (including students doing "scientific initiation"). This action would probably enrich all kinds of strategies aimed at boosting the quality, visibility and excellence of the research produced in Brazil. As pointed out by Angel Gurría (2013), OECD Secretary-General, "Brazil is adopting best practices in several areas but the best of Brazil is yet to come".

\section{ACKNOWLEDGMENTS}

Authors' work/research on research integrity is supported by grants from Conselho Nacional de Desenvolvimento Científico e Tecnológico (CNPq), Fundação Carlos Chagas Filho de Amparo à Pesquisa do Estado de Rio de Janeiro (FAPERJ) and Fundação de Amparo à Pesquisa do Estado de São Paulo (FAPESP). Martha M. Sorenson, Edson H. Watanabe and Debora Foguel have fellowships from CNPq. We thank Karina de Albuquerque Rocha, a "scientific initiation" student on research ethics at UFRJ supported by a CNPq scholarship, for diligent assistance with references. We also thank Professor Renan M.V.R. Almeida, for details on the course on scientific methodology at COPPE, and Professor Miguel Roig at St. John's University, for valuable comments on this manuscript.

\section{RESUMO}

Construir uma comunidade científica de alto nível requer uma composição de ingredientes de primeira linha: financiamento, treinamento, gestão, colaborações internacionais, criatividade, ética e uma compreensão de práticas de integridade em pesquisa. No cenário mundial, a abordagem dessas práticas tem sido uma prioridade na agenda de políticas científicas nos principais sistemas de pesquisa. Nesse contexto, as universidades têm um papel central na promoção de uma cultura de integridade em pesquisa, o que impõe desafios adicionais para professores, alunos e gestores - mas também oportunidades. No Brasil, as principais universidades e agências de fomento governamentais vêm colaborando na contrução desse projeto, mas ainda há muito o que ser feito.

Palavras-chave: Conduta responsável em pesquisa, integridade acadêmica, política científica, educação em ética em pesquisa, colaborações internacionais, $4^{\mathrm{a}}$ Conferência Mundial sobre Integridade em Pesquisa.

\section{REFERENCES}

AAAS - AMERICAN ASSOCIATION FOR THE ADVANCEMENT OF SCIENCE. 2011. Annual meeting. Science without borders. Available via: http://www.aaas.org/meetings/2011/

ABC - ACADEMIA BRASILEIRA DE CIÊNCIAS. 2013. Rigor e integridade na condução da pesquisa científica, $13 \mathrm{p}$.

ADAMS J. 2012. Collaborations: the rise of research networks. Nature 490: 335-336.

ADAMS J. 2013. Collaborations: the fourth age of research. Nature 497: 557-560.

AGÊNCIA FAPESP. 2014. $3^{\circ}$ BRISPE - Brazilian Meeting on Research Integrity, Science and Publications. Available at: http://agencia.FAPESP.br/agenda-detalhe/3_brispe brazilian_meeting_on_research_integrity_science_and_publications/19522/ 
ALISSON E. 2014. University of Michigan researcher says scientific misconduct has gone global. Agência FAPESP, Sept 17, 2014.

ANDERSON MS AND STENECK NH (Eds). 2010. International research collaborations: much to be gained, many ways to get in trouble. New York: Routledge, 296 p.

BRETAG T. 2013. Challenges in addressing plagiarism in education. PLoS Med 10(12): e1001574.

CARPENTER S. 2012. Harvard psychology researcher committed fraud, U.S. investigation concludes. Science Insider, Sept 6, 2012.

CGSa - COUNCIL FOR GRADUATE SCHOOLS. Best practices. Available at: http://www.cgsnet.org/scholarly-integrityand-responsible-conduct-research-rcr

CGSb - COUNCIL FOR GRADUATE SCHOOLS. The project for scholarly integrity. Available at: http://www.cgsnet.org/ project-scholarly-integrity

CLAVEY M. 2014. LERU universities want an 'ERA of change' after EU elections, May 21, 2014. horizon2020projects.com, available at: http://horizon2020projects.com/policy-research/ leru-universities-want-an-era-of-change-after-eu-elections/

CNPq - NATIONAL COUNCIL FOR SCIENTIFIC AND TeChnological Development. 2014. Diretrizes sobre integridade na pesquisa. Available at: http://www.cnpq.br/ web/guest/diretrizes

COMAs-Forgas R, Sureda-Negre J And SAlva-Mut F. 2010. Academic plagiarism prevalence among Spanish undergraduate students: an exploratory analysis. Biochem Med 20: 301-306.

CZELUSNIAK A. 2012. Universidades se armam contra o plágio. Gazeta do Povo, Jul 30, 2012. Available at http:// www.gazetadopovo.com.br/vida-universidade/nocampus/ conteudo.phtml?id=1279805

DAVIS M AND CARROLl J. 2009. Formative feedback within plagiarism education: is there a role for text-matching software. Int J Ed Integ 5: 2. Available at: http://www.ojs. unisa.edu.au/index.php/IJEI/issue/view/117

DEE TS AND JACOB BA. 2010. Rational ignorance in education: a field experiment in student plagiarism. NBER Working Paper No. 15672. Available at: http://www.nber.org/ papers/w15672

DINGELL JD. 1993. Misconduct in medical research. N Eng J Med 328: 1610-1615.

EDITORIAL. 2012. Repeat after me. Nature 488: 253.

ESF - EUROPEAN SCIENCE FOUNDATION. 2007. Research integrity: Global responsibility to foster common standards. Science Policy Briefing 30: 1-15.

Esteves B. 2011. Os alquimistas. Revista Piauí, Sept 2011. Available at: http://revistapiaui.estadao.com.br/edicao-60/ anais-da-ciencia/os-alquimistas

Esteves B. 2012. Má conduta em foco. Revista Piauí, May 24, 2012. Available at: http://revistapiaui.estadao.com.br/ blogs/questoes-da-ciencia/geral/ma-conduta-em-foco

Esteves B. 2014. Punição tardia. Revista Piauí, Feb 12, 2014. Available at: http://revistapiaui.estadao.com.br/blogs/ questoes-da-ciencia/geral/punicao-tardia
FANG FCF, SteEn RG AND CASAdeVAll A. 2012. Misconduct accounts for the majority of retracted scientific publications. Proc Natl Acad Sci USA 109(42): 1702817033.

FAPESP - RESEARCH FOUNDATION FOR THE STATE OF SÃO PAULO. 2014a. Código de boas práticas científicas. Avaliable at: http://www.FAPESP.br/boaspraticas/FAPESP-Codigo_ de_Boas_Praticas_Cientificas_2014.pdf

FAPESP - RESEARCH Foundation FOR the StATE OF SÃo PAulo. 2014b. Sumários de casos. Available at http:// www.fapesp.br/8577

Ferguson C, Marcus A AND Oransky I. 2014. Publishing: The peer-review scam. Nature 515: 480-482.

FMRP-USP - FACULTY OF MEDICINE OF RIBEIRÃO Preto OF the University of SÃo PAUlo. 2014 Ética e integridade em pesquisa. Available at: http://dourado.fmrp.usp.br/gestaoevento/upload/ d58383ce 3 bd 8 49e1 90 e4 37 a324bf2767 1 RCB0103.pdf

FOGUEL D. 2014. Research integrity at Brazilian universities: The case of the Federal University of Rio de Janeiro. Available at: http://www.fapesp.br/eventos/2014/08/ brispe/Debora.pdf

GRC - Global ReseARCh Council. Governing board. Available at: http://www.globalresearchcouncil.org/ governing-board

GURRÍA A. 2013. Launch of the economic survey of Brazil 2013. Available at: http://www.oecd.org/about/secretarygeneral/secretary-general-remarks-at-launch-of-theeconomic-survey-of-brazil-2013.htm

HEITMAN E AND LiTEWKA S. 2011. International perspectives on plagiarism and considerations for teaching international trainees.Urol Oncol 29: 104-108.

HOWARD RM. 2007. Understanding "Internet plagiarism". Computers and Composition 24: 3-15.

IBCCF - Institute of Biophysics Carlos Chagas Filho. Ética e integridade na pesquisa científica e tecnológica. Available at: http://www.biof.ufrj.br/pt-br/disciplinas oferecidas_biofisica

IBqM - Institute of MEdicAl BIOCHEMISTRY LEOPOLdO DE MEIS. 2015. Conduta responsável em pesquisa. Available at: http://www.bioqmed.ufrj.br/wp-content/ uploads/2015/01/qb_disciplina_conduta_responsavel_ pesquisa.pdf

IME - Military InSTITUTE OF ENGINEERING. 2012. Ética na pesquisa científica e tecnológica. Available at: http:// www.ime.eb.br/regulamento/56-mestrado/materiais.html

JAROFF L. 1991. Science under siege. Time, Aug 26, 1991.

JAYARAMAN KS. 2012. Indian science adviser caught up in plagiarism row. Nature News, Feb 24, 2012. Available at: http://www.nature.com/news/indian-science-advisercaught-up-in-plagiarism-row-1.10102\#auth-1

KreutzBerg GW. 2004. The rules of good science. EMBO Rep 5: 330-332.

KRIEGER JE. 2014. Brazil: banish bureaucracy. In: Capacity building: Architects of South American science. Nature 510: 209-212. 
KUPFERSCHMIDT K. 2013. University begins probe of German science minister's degree. Science Insider, Jan 23, 2013.

LÖFSTRÖM E. 2014. LERU Doctoral summer school "Doing the right things right"- Research integrity in a complex society. Available at: http://www.leru.org/files/general/ LERU\%20Summer\%20School\%202014_University\%20 of $\% 20$ Helsinki_Report_Flamma.pdf

MACQUARIE UNIVERSITY. 2014. Australia. Research integrity framework. Available at: http://www.research.mq.edu. au/about/research_office/ethics/research_integrity/docs/ Research_Integrity_Framework_2-9-14.pdf

MARQUES F. 2014. Do compromisso à ação. Revista Pesquisa FAPESP 223: 37-41.

MCCABE DL. 2005. Cheating among college and university students: A North American perspective. Int J Ed Integ 1. Available at: http://www.ojs.unisa.edu.au/index.php/ijei/ article/view/14/9

NAS - National ACAdemies of Sciences. 2010. Testimonials. NAS GUIRR Workshop. Examining core elements of international research collaboration. Available at: http://sites.nationalacademies.org/cs/groups/pgasite/ documents/webpage/pga_060362.pdf

NORMILE D. 2014a. RIKEN panel finds misconduct in controversial paper. Science 344: 23.

NORMILE D. 2014b. RIKEN shrinks troubled center. Science 345: 1110.

OECD - ORGANIZATION FOR ECONOMIC COOPERATION AND DeVelopment. 2007. Global Science Forum. Best practices for ensuring scientific integrity and preventing misconduct. Available at: http://www.oecd.org/ dataoecd/37/17/40188303.pdf

OECD - ORGANIZATION FOR ECONOMIC COOPERATION AND DEVELOPMENT. 2012. Science and innovation: Brazil. OECD science, technology and industry outlook 2012. Available at: http://www.oecd.org/brazil/sti-outlook2012-brazil.pdf

OECD - ORGANIZATION FOR ECONOMIC COOPERATION AND DEVELOPMENT. 2013. Economic survey of Brazil 2013. Available at: http://www.oecd.org/eco/surveys/economicsurvey-brazil.htm

PARK C. 2003. In other (people's) words: Plagiarism by university students literature and lessons. Assess Eval High Educ 28(5): 471-488.

PlaneTA COPPE. 2012. Coppe promove seminário sobre ética na pesquisa, Oct 11, 2012. Available at: http://www. planeta.coppe.ufrj.br/artigo.php?artigo $=1519$

POWER LG. 2009. University students' perceptions of plagiarism. J High Educ 80 (6): 643-662.

PUCRS - PONTIFICAL UNIVERSITY OF RIO GRANDE DO SUL. 2014. Coleção integridade na pesquisa em foco. ediPUCRS. Available at: http://ebooks.pucrs.br/edipucrs/ Ebooks/Web/integridadenapesquisa/index.html

SCHACHT WH. 2012. The Bayh-Dole Act: Selected issues in patent policy and the commercialization of technology. Congressional Research Service. https://www.autm.net/ Bayh_Dole_Act_Report.htm
SJR - Scimago Journal \& COUnTRY RANK. 1996-2013. Country Rankings. Available at: http://www.scimagojr. com/index.php

SURESH S. 2011. Moving toward global science. Science 333: 802.

TAKAHASHI F. 2011. USP demite professor por plágio em pesquisa. Folha de São Paulo, Feb 20, 2011.

THE CONCORDAT TO SUPPORT RESEARCH INTEGRITY. 2012. London: Universities UK, $24 \mathrm{p}$.

The Montreal Statement. 2013. $3^{\text {rd }}$ World Conference on Research Integrity. Available at: www.wcri2013.org

THE ROYAL SOCIETY. 2011. Knowledge, networks and nations. Global scientific collaboration in $21^{\text {st }}$ century. London: Elsevier, 113 p.

The Singapore StATEMENT ON RESEARCH INTEGRITY. 2010. Available at: http://www.singaporestatement.org/

TV COPPE. 2013. Available at: http://www.coppetv.coppe.ufrj. br/tvcoppe/exibirProgramacaoPlataforma;jsessionid=33E 7BD748D7E3BEBD527C88E970D791B

VAN NOORDEN R. 2014a. The impact gap: South America by the numbers. Nature 510: 202-203.

VAN NOORDEN R. 2014b. Transparency promised for vilified impact factor. Nature News, Jul 29, 2014.

VASCONCELOS SMR, STENECK NH, ANDERSON M, MASUdA H, Palacios M, Pinto JCS AND Sorenson MM. 2012. The new geography of scientific collaborations: Changing patterns in the geography of science pose ethical challenges for collaborations between established and emerging scientific powers. EMBO Rep 13(5): 404-407.

Velho L. 2011. Conceitos de ciência e a política científica, tecnológica e de inovação. Sociologias 26: 128-153.

WAGER E AND KLEINERT S. 2012. Saudi J Anaesth 6(2): 155160.

ZHANG Y. 2010. Chinese journal finds 31\% of submissions plagiarized. Nature 467(9): 153.

$4^{\text {th }}$ WCRI - World Conference on Research Integrity. 2015. Available at: www.wcri2015.org

$6^{\text {th }}$ International Integrity \& Plagiarism Conference. 2014. Promoting authentic assessment. UK. Available at: http://www.plagiarismconference.org/

I BRISPE - BRAZILIAN MEETING ON RESEARCH INTEGRITY, SCIENCE AND Publication Ethics. 2010. Available at: http://www.ibrispe.coppe.ufrj.br/material.php

II BRISPE - BRAZILIAN MEETING ON RESEARCH INTEGRITY, SCIENCE AND PUblication Ethics. 2012. Available at: http://www.iibrispe.coppe.ufrj.br/

III BRISPE - BRAZILIAN MEETING ON RESEARCH INTEGRITY, SCIENCE AND Publication Ethics. 2014a. Práticas Institucionais para a Promoção da Integridade Científica e a Conduta Responsável em Pesquisa. Available at: http:// www.FAPESP.br/8788

III BRISPE - BRAZILIAN MEETING ON RESEARCH INTEGRITY, SCIENCE AND PubliCATION ETHICS. 2014b. Strategy Meeting. Available at: http://www.FAPESP.br/8788 
